ISSN: 2302-8556

\title{
Respon Pasar Terhadap Pengumuman Akuisisi pada Perusahaan Pengakuisisi yang Terdaftar di BEI Tahun 2013-2017
}

\author{
Putu Putri Larasati ${ }^{1}$ \\ Dewa Gede Wirama ${ }^{2}$
}

${ }^{1}$ Fakultas Ekonomi dan Bisnis Universitas Udayana (Unud), Bali, Indonesia email: putrilarasati4@gmail.com/Telp: +62 87761330373

${ }^{2}$ Fakultas Ekonomi dan Bisnis Universitas Udayana (Unud), Bali, Indonesia

\begin{abstract}
ABSTRAK
Penelitian ini bertujuan untuk memperoleh bukti empiris mengenai respon pasar terhadap pengumuman akuisisi. Apabila terdapat kandungan informasi dalam pengumuman akuisisi, investor akan bereaksi dan mengakibatkan perubahan harga saham. Respon pasar dalam penelitian ini diukur dengan abnormal return, yaitu selisih antara return ekspektasian dan return realisasi. Abnormal return dalam penelitian ini diestimasi dengan menggunakan market-adjusted model, yang menggunakan data IHSG sebagai perhitungan untuk mendapatkan return ekspektasi. Jenis penelitian yang digunakan adalah kuantitatif. Sampel ditentukan melalui metode non probability dengan teknik purposive sampling. Jumlah perusahaan yang digunakan dalam penelitian ini berjumlah 51 perusahaan yang melakukan akuisisi dan merupakan perusahaan publik yang listing di Bursa Efek Indonesia (BEI) periode 2013-2017. Penelitian ini menggunakan uji one sample t-test. Hasil dari penelitian ini menunjukkan bahwa tidak terdapat respon pasar terhadap pengumuman akuisisi pada perusahaan pengakuisisi. Hal ini dibuktikan dengan signifikansi CAR sebesar 0,458 yang lebih besar dari 0,05 .
\end{abstract}

Kata Kunci:Abnormal return, respon pasar, akuisisi

\begin{abstract}
This study aims to obtain empirical evidence of market response on acquisitionsannouncement, investors will react and make changes in stock prices. The market response is measured with abnormal return, which the difference between the expected return and the realization return. Abnormal return in this research is estimated by using market-adjusted model, which uses JCI data as calculation to get expected return. The type of research used is quantitative. The sample is determined through non probability method with purposive sampling technique. The number of companies used in this study amounted to 51 companies that do the acquisition which is a public company listing on the Indonesia Stock Exchange (IDX) period 2013-2017. This study uses one sample t-test. The results of this study indicate that there is no market response to the announcement of acquisitions on acquirer firm. This is evidenced by a significance of CAR 0.458 greater than 0.05 .
\end{abstract}

Keywords: Abnormal return, market response, acquisitions 


\section{PENDAHULUAN}

Fenomena akuisisi di Indonesia telah mengalami fluktuasi. Berdasarkan hasil riset yang dilakukan oleh situs imaa-institute.org dalam 5 tahun terakhir, terdapat total 913 aktivitas akuisisi di Indonesia yang melibatkan akuisisi lintas batas negara maupun dalam negeri. Aktivitas tertinggi tercatat sebanyak 211 aktivitas pada tahun 2013 dengan nilai mencapai US\$ 9,58 milyar. Jumlah aktivitas tersebut sempat memunculkan harapan bahwa akuisisi Indonesia akan meningkat di tahuntahun berikutnya.

Tabel 1.

Data Aktivitas Akuisisi di Indonesia tahun 2013-2017

\begin{tabular}{ccc}
\hline Tahun & Jumlah Aktivitas Akuisisi & $\begin{array}{c}\text { Total Nilai } \\
\text { (dalam US\$) }\end{array}$ \\
\hline 2013 & 211 & 9.580 .000 .000 \\
2014 & 200 & 9.480 .000 .000 \\
2015 & 146 & 4.700 .000 .000 \\
2016 & 206 & 12.640 .000 .000 \\
2017 & 150 & 5.637 .414 .300 \\
\hline
\end{tabular}

Seperti yang terlihat pada tabel 1, di tahun 2014 dan 2015 terjadi tren penurunan yang cukup signifikan dibandingkan jumlah aktivitas akuisisi di tahun 2013 hingga mencapai 69 persen. Penurunan ini terjadi karena dampak dari Pemilu 2014 yang membuat investor cenderung wait and see hingga kondisi kembali stabil (Marketeers, 2015). Hal ini membuat akuisisi yang tercatat hanya sebanyak 146 aktivitas, sehingga nilai dari akuisisi Indonesia juga menurun. Di tahun 2016, aktivitas akuisisi kembali meningkat mencapai 206 aktivitas dan membuat lonjakan pada nilai akuisisi menjadi US\$ 12,64 milyar.Nilai ini merupakan puncak tertinggi nilai akuisisi dalam 5 tahun terakhir. 
Melihat aktivitas akuisisi yang semakin berkembang di Indonesia, pemerintah mulai membuat regulasi untuk mengatur jalannya akuisisi. UndangUndang Nomor 1 Tahun 1995 tentang Perseroan Terbatas mengawali diberlakukannya aktivitas akuisisi bagi perusahaan non perbankan. Selanjutnya 4 tahun kemudian, pemerintah mengeluarkan Undang-Undang Nomor 5 tahun 1999 tentang Larangan Praktek Monopoli dan Persaingan Usaha Tidak Sehat agar aktivitas akuisisi dapat lebih terkendali. Bersamaan dengan peraturan tersebut, dibentuk pula Komisi Pengawasan Persaingan Usaha (KPPU) sebagai lembaga independen yang mengawasi pelaksanaan dari Undang-Undang tersebut.

Pada dasarnya perusahaan yang melakukan akuisisi memiliki harapan akan mendatangkan keuntungan. Keadaan dimana perusahaan saling menguntungkan akan terjadi jika peristiwa akuisisi menciptakan sebuahsynergy. Seperti yang dijelaskan oleh Sartono (2001), dengan melakukan akuisisi maka dapat diperoleh sinergi, dimana nilai penjumlahanyang lebih besar dari jumlahan nilai dari bagiannya atau dapat diilustrasikan dengan $2+2=6$. Sesuai dengan pernyataan tersebut, akuisisi menjadi sinergi ketika perusahaan mencapai skala ekonomis sehingga dapat meningkatkan nilai perusahaan. Salah satu skala ekonomis yang ingin dicapai dalam melakukan akuisisiadalah memanfaatkan dan menggunakan sumber daya yang ada secara maksimal oleh perusahaan (Heykal dan Hennisia, 2015).

Di sisi lain, akuisisi merupakan strategi bisnis yang penuh risiko. Dampak yang diberikan dari kegiatan akuisisi dapat dikatakan cukup signifikan terutama bagi perusahaan yang pengakuisisi. Perusahaan pengakuisisi yang akan 
menanggung risiko-risiko dari akuisisi. Menurut Komisi Pengawas Persaingan Usaha (KPPU) dalam situsnya pada tahun 2011, beberapa studi menyatakan 83 persen akuisisi gagal memberikan keuntungan bagi pemangku kepentingan dan lebih dari separuhnya merusak nilai-nilai yang ada. Salah satu alasan kegagalan ini adalah proses akuisisi yang menimbulkan perang penawaran (bidding war)atau beberapa pihak lain yang ikut menawar sehingga memicu perang penawaran. Bidding war ini akan membuat harga eksekusi semakin melambung sehingga pemegang saham perusahaan pengakuisisi dapat mengalami keterpurukan dan terlalu membebani perusahaan pengakuisisi dengan hutang yang sangat banyak.

Wolk dkk., (2013) mengatakan bahwa, pemegang saham melakukan investasi untuk memaksimalkan kesejahteraan mereka. Maka dari itu, pemegang saham perlu tahu apa saja informasi yang ada tentang hal-hal yang terjadi pada perusahaan serta dampaknya terhadap keputusan investasi yang akan diambil. Pengumuman akuisisi dapat memunculkan banyak informasi mengenai transaksi yang potensial (Rani dkk., 2013). Informasi yang ada akan membentuk suatu kepercayaan baru dikalangan investor (Gusti, 2017). Kepercayaan baru yang muncul akan mengubah harga dari surat-surat berharga atau dapat dikatakan bahwa pengumuman akuisisiakan menimbulkan suatu respon pasar. Respon ini dapat berupa kenaikan maupun penurunan dari harga sekuritas (saham) perusahaan di sekitar tanggal pengumuman akuisisi tersebut. Respon pasar dari suatu peristiwa dapat diukur dengan abnormal return (Jogiyanto, 2015: 609).

Abnormal return dapat diartikan sebagai tingkat pengembalian yang dihasilkan oleh saham atau portofolio dalam periode tertentu, dimana tingkat 
pengembalian ini berbeda dengan tingkat pengembalian yang diharapkan (expected rate of return) (Shella, 2001). Abnormal return akan dikatakan positif ketika dapat melampaui nilai expected of return. Secara rasional, perusahaan akan mengharapkan adanya abnormal return positif setelah menjalankan strategi bisnis terutama akuisisi. Hal ini dikarenakan jika respon pasar positif maka otomatis akan terjadi peningkatan kesejahteraan para investor.

Penelitian yang meneliti mengenai pengumuman akuisisi sudah relatif banyak dilakukan namun menunjukkan adanya hasil yang beragam. Salah satunya adalah penelitian yang dilakukan oleh Dananjaya dan Wiagustini (2015), Rusnanda, dkk. (2013), Firmansyah (2013), serta Darlis dan Zirman (2011) menemukan tidak ada perbedaan abnormal return perusahaan yang signifikan pada saat sebelum dan sesudah merger dan akuisisi, hal ini berarti merger dan akuisisi tidak memberikan informasi sehingga tidak membuat perbedaan yang signifikan pada abnormal return perusahaan.

Berbeda dengan penelitian yang dilakukan oleh Wong dan Cheung (2009), Uygur, dkk. (2014), Khanal, dkk. (2014) dan Edward (2012) yang menemukan bahwa terdapat perbedaan yang signifikan antara abnormal return sebelum dan sesudah merger dan akuisisi. Penelitian-penelitian ini menunjukkan bahwa peristiwa merger dan akuisisi memuat suatu informasi yang membuat investor merespon peristiwa ini. Informasi yang terkandung dapat memberikan signal baik sehingga investor tertarik untuk melakukan trading saham. Berdasarkan hasil penelitian terdahulu yang memberikan hasil yang tidak konsisten, maka penelitian mengenai respon pasar ini menarik untuk diteliti. Peneliti mencoba untuk menguji 
Putu Putri Larasati dan Dewa Gede Wirama. Respon ...

kembali mengenai Respon Pasar Terhadap Pengumuman Akuisisi pada Perusahaan Pengakuisisi (Studi pada Perusahaan yang Terdaftar di BEI Tahun 2013-2017)

Berdasarkan pemaparan pada latar belakang, maka rumusan masalah dalam penelitian ini adalah apakah terdapat respon pasar disekitar pengumuman akuisisiperusahaan pada perusahaan pengakuisisi? Adapun tujuan penelitian ini adalah untuk membuktikan apakah terdapat respon pasar disekitar pengumuman akuisisi perusahaan pada perusahaan pengakuisisi. Harapannya penelitian ini dapat memberikan pemahaman yang lebih luas mengenai pengaruh pengumuman akuisisi yang dilakukan perusahaan. Di samping itu, diharapkan dapat memberikan kontribusi dalam kajian empiris dan dijadikan perbandingan, pengembangan, dan penyempurnaan dari penelitian-penelitian yang telah dilakukan sebelumnya.

Hanafi (2004) mendefinisikan bahwa teori efisiensi pasar adalah teori yang membahas mengenai harga atau nilai sekuritas yang mencerminkan secara penuh semua informasi yang tersedia pada informasi tersebut. Respon pasar terhadap informasi merupakan hal yang perlu diperhatikan oleh perusahaan, karena harga dari saham perusahaan akan bergantung pada investor. Jika pasar merespon dengan cepat dan tepat terhadap suatu peristiwa sehingga mencapai harga keseimbangan yang baru dan telah sepenuhnya mennggambarkan informasi yang tersedia, maka pasar tersebut merupakan pasar efisien (Jogiyanto, 2015: 548). Jadi semakin cepat informasi baru tercermin pada harga sekuritas, maka pasar akan semakin efisien. 
Menurut Jogiyanto (2015: 548), efisiensi pasar dari sudut informasi (informatonally efficient market) ada tiga, yaitu efisiensi pasar bentuk lemah (weak form). Pasar dikatakan efisiensi bentuk lemah jika harga atau nilai yang tercantum dalam sekuritas tersebut secara penuh mencerminkan informasi masa lampau (past price changes). Efisiensi pasar bentuk setengah kuat (semi strong form). Pasar dikatakan semi strong formkuat ketika harga yang tercantum dalam sekuritas secara penuh mencerminkan semua informasi yang dipublikasikan termasuk informasi yang berada di laporan keuangan perusahaan emiten. Pengujian pasar bentuk setengah kuat dilakukan dengan menguji kecepatan harga sekuritas melakukan penyesuaian terhadap informasi baru di pasar modal.

Efisiensi pasar bentuk kuat (strong form). Pasar dikatakan efisien bentuk kuat saat harga yang secara penuh mencerminkan semua informasi baik yang tersedia di pasar modal maupun yang bersifat privat. Hal ini dapat terjadi jika pelaku pasar merupakan investor yang canggih yang mampu memahami dan menginterpretasikan informasi dengan cepat dan baik. Dalam hal ini, investor tidak akan bisa mendapatkan abnormal return karena investor yang merespon dengan cepat menyebabkan harga suatu sekuritas akan menyesuaikan dengan cepat juga.

Agar dapat mengurangi asimetri informasi yang terjadi, manajemen perlu memberikan sinyal kepada investor agar meyakinkan investor bahwa perusahaan mereka pantas untuk dijadikan tempat investasi. Wolk dkk., (2013) mengatakan bahwa, salah satu cara untuk mengurangi asimetri informasi adalah dengan mengeluarkan informasi keuangan yang dapat dipercaya dan akan mengurangi ketidakpastian mengenai prospek perusahaan yang akan datang. Informasi yang dipublikasikan oleh perusahaan sebagai sebuah pengumuman akan memberikan 
sinyal bagi investor dalam pengambilan keputusan investasi (Jogiyanto, 2015: 547). Setelah informasi diumukan, pelaku pasar akan menginterpretasikan dan menganalisis informasi tersebut sebagai sinyal yang baik (good news) atau sinyal buruk (bad news). Sebagai contoh, saat perusahaan melakukan pengumuman akuisisi maka investor akan berespon bahwa perusahaan telah memberikan sinyal baik. Perusahaan yang memberikan sinyal baik diprediksikan akan mempunyai prospek yang baik di masa mendatang sehingga investor akan tertarik untuk melakukan perdagangan saham. Seperti halnya pengumuman akuisisi yang merupakan sebuah informasi atau sinyal yang dikeluarkan oleh perusahaan (Hartono dkk., 2012).

Menurut PSAK No. 22 paragraf 08, penggabungan usaha (business combination) adalah penyatuan dua atau lebih perusahaan (entitas) yang terpisah menjadi satu entitas ekonomi karena satu perusahaan menyatu dengan perusahaan lain atau memperoleh kendali (control) atas aktiva dan operasi perusahaan lain (IAI, 2016). Gitman dan Zutter (2012) mengatakan bahwa akuisisidapat dikategorikan menjadi tiga jenis, yaitu horizontal. Akuisisi horizontal terjadi saat perusahaan yang bergabung adalah perusahaan dengan industri sejenis. Sebagai contoh saat akuisisi yang terjadi dua perusahaan industri rokok. Akuisisi jenis ini akan menghasilkan perluasan operasi perusahaan dalam jenis produk tertentu dan sekaligus akan mengurangi jumlah pesaing dalam waktu yang bersamaan. Kemudian akuisisi vertikal, yang merupakan akuisisi yang terjadi ketika perusahaan mengakuisisi suatu perusahaan yang berada dalam tahapan proses produksi (supply chain), seperti pemasok atau pelanggan. Sebagai contoh sebuah 
akuisisi antara perusahaan penghasil mobil dengan perusahaan yang menghasilkan spare part mobil seperti AC dan ban. Akuisisi vertikal yang dilakukan perusahaan akan dapat menurunkan harga pokok produk yang lebih rendah sehingga harga jual pun dapat menurun. Hal ini dapat membuat volume penjualan dapat meningkat dan menguntungkan perusahaan. Selanjutnya adalah akuisisi konglomerasi merupakan penggabungan antara perusahaan yang memiliki usaha yang berbeda-beda dan tidak terkait (diversifikasi). Sebagai contoh yaitu akuisisi antara perusahaan penghasil tekstil dengan perusahaan yang menghasilkan makanan cepat saji. Konglomerasi dilakukan untuk variasi usaha dan dapat sebagai sumber pemasukan di masa mendatang, sehingga jangkauan konsumen akan lebih luas lagi kedepannya.

Kenaikan kekayaan pemegang saham digambarkan melalui kenaikan harga saham perusahaan yang membuat pemegang saham akan mendapatkan keuntungan atas peristiwa akuisisiyang terjadi. Menurut Gitman dan Zutter (2012), motif-motif perusahaan melakukan akuisisi adalah pertumbuhan atau diversifikasi, dimana perusahaan menginginkan pertumbuhan yang cepat dalam ukuran dan market share atau diversifikasi produknya. Sinergi, yang didapatkan ketika overhead perusahaan yang melakukan akuisilebih rendah dari perusahaan yang tidak melakukan akuisisi, terutama saat akuisisi dengan industrisejenis. Sebagai contoh akuisisi yang dilakukan oleh PT XL Axiata Tbk terhadap PT Axis Telekom Indonesia pada tahun 2014, dimana kedua perusahaan ini merupakan perusahaan sejenis yang bergerak di bidang komunikasi. Penggalangan dana, beberapa perusahaan sering melakukan akuisisi untuk meningkatkan kemampuan 
Putu Putri Larasati dan Dewa Gede Wirama. Respon ...

fund raisingnya. Hal ini dilakukan karena perusahaan tidak mungkin mendapatkannya dari ekspansi internal, dan sangat mungkin didapatkan dari penggabungan usaha eksternal. Perusahaan kecil akan mengincar dan bergabung dengan perusahaan yang memiliki likuiditas tinggi, sehingga perusahaan kecil tadi dapat meningkatkan likuiditasnya dan memberikan peningkatan daya pinjam perusahaan. Meningkatkan keterampilan manajerial atau teknologi, seringkali perusahaan tidak dapat berkembang secara baik karena kekurangan-kekurangan di berbagai area seperti manajemen dan keterbelakangan teknologi dan ketidakmampuan biaya dalam mengembangkan teknologinya. Akuisisidapat menjadi pilihan, karena perusahaan yang bergabung dengan perusahaan yang sudah berkembang dapat memiliki personil manajemen yang dibutuhkan dan dapat berkontribusi untuk memaksimalkan kekayaan pemilik. Pertimbangan pajak, kerugian pajak (tax loss) dapat merugikan perusahaan hingga lebih dari 20 tahun atau hingga kerugian tersebutdapat tertutupi. Maka dari itu,tax loss berguna ketika perusahaan yang mengalami keuntungan mengakuisisi perusahaan yang mengalami kerugian, sehingga perusahaan dapat membayar pajaknya lebih sedikit. Meningkatkan likuiditas kepemilikan,akuisisi dari sekian perusahaan kecil dan perusahaan yang besar dapat memberikan likuiditas yang lebih baik bagi pemiliki perusahaan kecil. Defense against takeover, ketika perusahaan yang menjadi sasaran pengambilalihan tidak menyetujui akuisisi, perusahaan akan menjalankan taktik bertahan. Dimana perusahaan yang ddiinginkan akan mengambil tambahan utang untuk membiayai akuisisi bertahannya. Ketika utang 
perusahaan yang diincar menjadi terlalu banyak maka acquirer akan kembali memikirkan untuk mengakuisisi perusahaan yang diincarnya.

Total keuntungan atau return total merupakan keseluruhan return yang didapatkan investor dari kegiatan investasinya dalam suatu periode tertentu. Return total terdiri dari komponen yield dan capital gain (loss) (Jogiyanto, 2015: 196). Yield merupakan pemasukan berupa cash terhadap harga investasi satu kegiatan investasi pada periode waktu tertentu, sedangkan capital gain (loss) merupakan selisih harga investasi sekarang relatif dengan harga pada periode yang lalu. Jika harga investasi pada periode sekarang lebih tinggi dari harga investasi pada periode yang lalu maka akan terjadi keuntungan modal (capital gain) dan akan terjadi sebaliknya jika harga investasi menurun pada periode sekarang maka akan terjadi kerugian modal (capital loss).

Dalam kegiatan berinvestasi seringkali return yang didapatkan tidak sesuai dengan yang telah diharapkan. Selisih antara return sesungguhnya dengan normal retutn (return yang diharapkan) disebut dengan abnormal return. Abnormal return dapat terjadi jika suatu pengumuman yang mengandung informasi direspon oleh pasar. Abnormal return dihitung dengan membandingkan besar return yang diharapkan dengan besaran return yang terjadi. Apabila return yang terjadi lebih tinggi dari return yang diharapkan, maka dapat dikatakan terjadi abnormal return. Menurut Brown dan Warner (1985) terdapat 3 model yang digunakan untuk mengestimasi abnormal return, yaitu: mean adjusted model, yaitu model sesuaian rata-rata yang menganggap bahwa return ekspektasian bernilai konstan yang sama dengan rata-rata return realisasian sebelumnya selama periode estimasi. Market 
Putu Putri Larasati dan Dewa Gede Wirama. Respon ...

model, perhitungan dengan model ini dilakukan dengan dua tahap yaitu membentuk model ekspektasi dengan menggunakan data realisasi selama periode estimasi yang kemudian menggunakan model ekspektasi ini untuk mengestimasi return ekspektasian di periode jendela. Market adjusted model, dengan menggunakan model ini maka tidak perlu menggunakan periode estimasi untuk membentuk model estimasi, karena return sekuritas yang diestimasi adalah sama dengan return Indeks Harga Pasar atau IHSG.

Penawaran dan permintaan akan menciptakan keseimbangan harga dalam pasar. Penawaran dan permintaan ini akan berubah seiring dengan masuknya informasi ke pasar sehingga akan tercapai pergeseran ke titik ekuilibrium yang baru. Informasi yang masuk akan direspon oleh investor, apabila informasi tersebut memiliki kandungan informasi maka diharapkan pasar akan merespon pada saat pengumuman (Sanjiwani dan Jati, 2017). Apabila pengumuman akuisisiini memiliki kandungan informasi maka diharapkan investor akan merespon yang dilihat dari adanya abnormal returndisekitar pengumuman.

Penelitian yang dilakukan oleh Astri (2010) menemukan bahwa pengumuman merger dan akuisisiternyata mampu menghasilkan rata-rata abnormal return yang positif. Pengamatan yang dilakukan dalam penelitian ini adalah 41 hari, yaitu 20 hari sebelum pengumuman, hari pengumuman, dan 20 hari setelah pengumuman. Hasil yang diperoleh sebanyak 11 hari (27\%) rata-rata abnormal return negatif dan sebanyak 30 hari (73\%) pengamatan memberikan rata-rata abnormal return yang positif. Hal ini berarti menunjukkan bahwa secara umum keputusan akuisisi perusahaan telah direspon baik oleh investor. 
Isa dan Lee (2011) juga meneliti mengenai respon pasar pada pasar saham Malaysia. Penelitian ini menunjukkan adanya abnormal return positif yang signifikan pada hari pengumuman merger dan akuisisi dan pada $\mathrm{H}+1$ pengumuman. Serupa dengan penelitian ini, Astria (2013) juga mengungkapkan bahwa terdapat perbedaan abnormal return yang signifikan pada saat sebelum dan sesudah pengumuman merger dan akuisisi. Moffett (2013) juga meneliti mengenai reaksi pasar terhadap akuisisi pada bank di Amerika. Hasil dari penelitian ini menunjukkan peristiwa merger dan akuisisi mendapatkan average actual return yang positif pada kedua perusahaan, baik perusahaan target maupun perusahaan pengakuisisi. Hal ini berarti bahwa pasar merespon atas pengumuman akuisisi yang dilakukan perusahaan. Berdasarkan uraian dari beberapa peneliti sebelumnya, maka peneliti merumuskan hipotesis sebagai berikut:

$\mathrm{H}_{1}$ : Terdapat respon pasar disekitar pengumuman akuisisi pada perusahaan pengakuisisi.

\section{METODE PENELITIAN}

Pendekatan yang digunakan pada penelitian ini adalah pendekatan kuantitatif (positivism). Penelitian ini menggunakan event study yang menggunakan periode 7 hari dalam rentang waktu pengumuman akuisisiyang ditransformasikan kedalam angka $-3,-2,-1,0,1,2,3$. Periode jendela peristiwa didbuat berdasar pada penelitian yang dilakukan sebelumnya. Hal ini memiliki tujuan agar meminimalisir confounding effect atau tercampurnya informasi dari corporate action lainnya (Dewi, 2014).

Penelitian ini dilakukan pada perusahaan yang telah terdaftar di Bursa Efek Indonesia dengan cara mengakses www.idx.co.id dan www.kppu.go.id. Obyek 
Putu Putri Larasati dan Dewa Gede Wirama. Respon ...

dalam penelitian ini adalah perusahaan yang mengumumkan tindakan akuisisi dan telah terdaftar di Bursa Efek Indonesia.Variabel yang digunakan dalam penelitian ini adalah respon pasar yang diproyeksikan dengan abnormal return. Setelah abnormal return dari masing-masing sekuritas dihitung, selanjutnya adalah menghitung cumulative abnormal return (CAR) setiap sekuritas dengan cara menjumlahkan seluruh abnormal return selama event window (h-3 sampai $\mathrm{h}+3)$. Alasan menggunakan CAR dalam penelitian ini karena menurut Mackinlay (1997), konsep dari CAR diperlukan untuk mengakomodasi beberapa event window. Jadi, untuk melihat besarnya abnormal return perusahaan selama event window, maka CAR harus dihitung secara keseluruhan selama event window.

\section{Tabel 2}

\section{Hasil Pemilihan Sampel}

\begin{tabular}{ccc}
\hline No & \multicolumn{1}{c}{ Kriteria } & $\begin{array}{c}\text { Jumlah } \\
\text { Perusahaan }\end{array}$ \\
1 & $\begin{array}{l}\text { Saham yang tercatat sebagai emiten di Bursa Efek Indonesia } \\
\text { (BEI) yang melakukan akuisisi tahun 2013-2017 }\end{array}$ & 52 \\
$2 \quad \begin{array}{l}\text { Perusahaan yang melakukan corporate } \\
\text { window }\end{array}$ & $(1)$ \\
\hline Jumlah Sampel Akhir & 51 \\
Jumlah Pengamatan (hari) & 7 \\
Jumlah Sampel & 357 \\
\hline Sumber: & \\
\end{tabular}

Pada penelitian ini model estimasi yang digunakan untuk menghitung returnekspektasi adalah market-adjusted model. Untuk dapat mengetahui terdapatnya abnormal return disekitar pengumuman akuisisi, perhitungannya dapat dirumuskan sebagai berikut:

- Menghitung actual return (return sesungguhnya) (Jogiyanto, 2015:265): 


$$
\text { Rit }=\frac{\mathrm{Pit}-\mathrm{Pi}, \mathrm{t}-1}{\mathrm{Pi}, \mathrm{t}-1}
$$

Keterangan:

Rit : :Return sesungguhnya yang terjadi untuk sekuritas ke-i pada periode peristiwa ke $\mathrm{t}$

$\mathrm{Pi}, \mathrm{t} \quad$ : Harga sekarang relatif

Pi,t-1 : Harga sebelumnya

- Menghitung return pasar harian (Jogiyanto, 2015: 648):

$\mathrm{Rmt}=\frac{\text { IHSGt }-\mathrm{IHSGt}-1}{\text { IHSGt }-1}$.

Keterangan:

Rmt :Return pasar pada waktu ke-t

IHSGt : Indeks Harga Saham Gabungan hari ke t

IHSGt-1 : Indeks Harga Saham Gabungan hari ke t-1

- Menghitung abnormal return dengan menggunakan market adjusted model untuk masing-masing emiten (Jogiyanto, 2015: 659):

$\mathrm{RTNi}, \mathrm{t}=\mathrm{Ri}, \mathrm{t}-\mathrm{Rm}, \mathrm{t}$

Keterangan:

$\mathrm{RTNi}, \mathrm{t} \quad$ :Abnormal return yang terjadi untuk sekuritas ke i periode estimasi ke $\mathrm{t}$

Ri,t $\quad$ : Return realisasian yang terjadi untuk sekuritas ke i periode estimasi $\mathrm{t}$

$R m, t \quad:$ Return indeks pasar pada periode estimasi ke $\mathrm{t}$

- Menghitung cumulative abnormal return (Suwanna, 2012)

$\mathrm{CAR}=\sum_{\mathrm{t}=\mathrm{T}}^{\mathrm{T} 7} \mathrm{RTNit}$

Keterangan:

CAR :cumulative abnormal return

RTNi,t : Abnormal return yang terjadi untuk sekuritas ke i periodeke $\mathrm{t}$ 
Putu Putri Larasati dan Dewa Gede Wirama. Respon ...

Populasi penelitian ini adalah seluruh perusahaan yang terdaftar di Bursa Efek Indonesia sampai tahun 2017, yang melakukan akuisisi yaitu sebanyak 52 emiten. Penentuan sampel dari populasi penelitian ini diambil dengan menggunakan pendekatan nonprobabilitas dengan metode purposive sampling berdasarkan beberapa kriteria mencakup: 1) saham telah terdaftar di BEI, 2) perusahaan melakukan akuisisi pada periode 2013-2017, 3) mempunyai tanggal pengumuman akuisisi yang jelas, 4) tidak melakukan corporate action lainnya selama event window seperti stock split, pembagian deviden, dsb. Berdasarkan kriteria yang telah ditentukan, maka jumlah sampel yang digunakan dalam penelitian ini adalah 51 emiten.

Pada penelitian ini menggunakan metode pengumpulan data observasi non partisipan. Adapun pengujian yang digunakan dalam penelitian ini, antara lain Analisis statistik deskriptif, market adjusted model, uji normalitas, uji hipotesis dengan one sample t-test. Market Adjusted Model digunakan untuk menghitung tingkat abnormal return. Menurut (Jogiyanto, 2015: 568), penduga yang terbaik jika menggunakan market-adjusted model untuk mengestimasi return suatu sekuritas adalah return indeks pasar ada saat itu. Prosedur pengujiannya diawali dengan memperoleh data mengenai pengamatan akuisisidan menentukan tanggal pengumuman sebagai $\mathrm{t}=0$, kemudian mendapatkan data mengenai harga sahaam perusahaan yang melakukan akuisisidari $\mathrm{h}-3$ sampai $\mathrm{h}+3$, sesuai dengan periode jendela dari penelitian yang dilakukan sebelumnya. Menghitung actual return masing-masing sampel pada periode penelitian. Menghitung return pasar 
harianmasing-masing sampel pada periode penelitian. Menghitung abnormal return masing-masing sampel pada periode penelitan.

One sample t-test merupakan alat uji untuk melihat apakah terdapat atau tidak respon pasar yang diproyeksikan dengan abnormal return pada pengumuman akuisisi dengan test value yang ditetapkan sama dengan 0. Adapun prosedur dari one sample t-test adalah membuat rumusan hipotesis $\mathrm{H}_{1}$ yaitu terdapat respon pasar disekitar pengumuman akuisisi pada perusahaan pengakuisisi. Kriteria penerimaan $\mathrm{H}_{1}$ ditolak jika $P$ value $(\mathrm{sig})>\alpha(0,05)$ dan $\mathrm{H}_{1}$ diterima jika jika $P$ value $($ sig $) \leq \alpha(0,05)$.

\section{HASIL DAN PEMBAHASAN}

Pada tabel 3 di bawah ini menampilkan hasil analisis statistik deskriptif yang memberikan gambaran mengenai data sampel yang telah dikumpulkan.

\section{Tabel 3.}

Statistik Deskriptif

\begin{tabular}{lcllll}
\hline Keterangan & N & Minimum & Maksimum & Mean & $\begin{array}{l}\text { Deviasi } \\
\text { Standar }\end{array}$ \\
\hline Return realisasi & 51 & $-0,1272$ & 0,2579 & 0,0123 & 0,6874 \\
Return ekspektasi & 51 & $-0,1727$ & 0,0727 & 0,0038 & 0,0353 \\
CAR & 51 & $-0,1501$ & 0,2703 & 0,0077 & 0,0741 \\
\hline
\end{tabular}

Sumber: Data diolah, 2017

Berdasarkan tabel 3, return realisasi yang dihitung dengan jumlah sampel sebanyak 51 perusahaan selama tujuh hari pengamatan memiliki nilai minimum sebesar -0,1272 dan nilai maksimum sebesar 0,2579. Return ekspektasi dihitung menggunakan market adjusted model menghasilkan return ekspektasi minimum sebesar -0,1727 dan nilai maksimum sebesar 0,0727. Cumulative abnormal return 
Putu Putri Larasati dan Dewa Gede Wirama. Respon ...

(CAR) secara keseluruhan menghasilkan nilai minimum sebesar -0,1501,nilai minimum ini dimiliki oleh PT Saratoga Investama Sedaya Tbk dengan kode saham SRTG. Nilai maksimum CAR sebesar 0,2703 dimiliki oleh PT Plaza Indonesia Realty Tbk dengan kode saham PLIN. Rata-rata CAR yang bernilai positif, yaitu 0,0077 menunjukkan bahwa secara umum, perusahaan-perusahaan selama periode pengamatan menghsilkan return saham yang positif, yang berarti pengumuman akuisisi memiliki kandungan informasi. Berdasarkan tabel 4 hasil penelitian uji normalitas menggunakan variabel CAR menghasilkan nilai probabilitas sebesar $0,484>0,05$, hal ini berarti semua data CAR pada peristiwa pengumuman akuisisi terdistribusi normal.

Tabel 5.

Hasil Uji One Sample t-test

\begin{tabular}{cccccc}
\hline Variabel & Jumlah & t-hitung & Sig. (2-tailed) & Kriteria & Keterangan \\
\hline CAR & 51 & 0,748 & 0,458 & 0,05 & $\begin{array}{c}\text { Tidak } \\
\text { signifikan }\end{array}$ \\
\hline
\end{tabular}

Sumber: Data diolah, 2017

Berdasarkan tabel 5,dihasilkan bahwa cumulative abnormal return (CAR) selama periode pengamatan memperoleh nilai $\mathrm{t}=0,748$ dengan nilai probabilitas sebesar 0,458 . Nilai probabilitas $0,458>\alpha(0,05)$ yang berarti $\mathrm{H}_{1}$ ditolak. Hal ini berarti tidak terdapat respon pasar disekitar pengumuman akuisisi. Berdasarkan hasil uji hipotesis menunjukkan bahwa tidak terdapat respon pasar yang signifikan disekitar pengumuman akuisisi. Hal ini ditunjukkan dengan nilai signifikansi di atas $0,05(0,458)$, dengan demikian $\mathrm{H}_{1}$ yang menyatakan bahwa terdapat respon pasar disekitar pengumuman akuisisi pada perusahaan pengakuisisi ditolak. 
Pengujian ini menunjukkan bahwa para pelaku pasar modal khususnya investor sudah terbiasa menanggapi peristiwa akuisisi, sehingga peristiwa tersebut tidak mempengaruhi pilihan investasi dari para pelaku pasar. Hal ini kemungkinan besar disebabkan oleh alasan dibalik terjadinya akuisisi, seperti untuk menyelamatkan perusahaan dari kebangkrutan hingga risiko besar seperti hutang besar yang dihadapi perusahaan pengakuisisi pasca akuisisi.

Implikasi penelitian ini dibagi atas dua jenis, yaitu 1) Implikasi teoretis, yaitu penelitian ini dapat mendukung teori sinyal, dimana manajemen perlu memberikan sinyal kepada investor untuk mengurangi asimetri informasi. Hal ini dilakukan agar meyakinkan investor bahwa perusahaan mereka pantas untuk dijadikan tempat investasi. Pengumuman akuisisi merupakan salah satu sinyal yang diberikan oleh manajemen. Informasi ini ternyata dianalisis sebagai sinyal yang baik (good news) oleh investor; 2) Implikasi praktis berikutnya adalah penelitian ini dapat menambah wawasan dan pengetahuan penulis mengenai respon pasar terhadap pengumuman akuisisi. Selain itu bagi perusahaan, penelitian ini dapat memberikan informasi mengenai mengenai bagaimana pasar akan merespon terhadap pengumuman akuisisi yang dilakukan oleh perusahaan. Bagi investor, penelitian dapat dijadikan sebagai pertimbangan bagi investor dalam mengambil keputusan terkait dengan investasi pada perusahaan-perusahaan yang menyelenggarakan akuisisi.

\section{SIMPULAN}

Berdasarkan pembahasan pada bab sebelumnya, maka dapat ditarik simpulan bahwa pasar merespon positif terhadap pengumuman akuisisi meskipun tidak 
Putu Putri Larasati dan Dewa Gede Wirama. Respon ...

terjadi peningkatan abnormal return disekitar pengumuman. Lebih tegasnya penelitian ini menunjukkan bahwa pengumuman akuisisi tidak menimbulkan respon pasar. Hasil ini tidak mendukung penelitian sebelumnya yang dilakukan oleh Bessler dan Murtagh (2002), Elad (2017), Mirna, dkk (2013), Joash dan Njangiru (2015). Penelitian ini konsisten dengan penelitian yang dilakukan oleh Malau, dkk (2017), Liliana, dkk (2016), Rahman (2018).

Saran yang dapat diberikan adalah bagi para investor, sebaiknya melihat latar belakang dilakukannya akuisisi, seperti keadaan perusahaan yang diakuisisi (perusahaan target). Akan lebih baik jika menghindari investasi pada perusahaan yang mengakuisisi perusahaan target yang sedang terlilit masalah atau mengalami kebangkrutan, karena dapat meningkatkan risiko kesulitan keuangan bagi perusahaan pengakuisisi dan pemegang sahamnya. Bagi penelitian selanjutnya, kelemahan dari penelitian ini adalah tidak membedakan perusahaan yang melakukan akuisisi pada perusahaan yang mengalami kesulitan keuangan dan tidak, sehingga hasil yang diberikan tidak dapat mencerminkan respon sesuai dengan keadaan perusahaan pengakuisisi. Selain itu, dapat juga dipertimbangkan untuk menggunakan mean-adjusted model dan market model dalam menghitung abnormal return, sehingga dapat dilakukan perbandingan hasil penelitian.

\section{REFERENSI}

Astria, N. 2013. Analisis Dampak Pengumuman Merger dan AkuisisiTerhadap Abnormal return Saham Perusahaan Akuisitor yang Terdaftar di BEI Tahun 2006-2008. Jurnal Ilmiah Mahasiswa FEB, 1(2), hal.1-13.

Bessler, Wolfgang dan Murtagh, James P. 2002. The Stock Market Reaction to Cross-Border Acquisitions of Financial Services Firm: An Analysis of Canadian Banks. Journal of Institution and Money, 12, hal 419-440. 
Brown, S.J., and Warner, J.B. 1985. Using daily Stock Return, The Case of Event Studies. Journal of Financial economics, 14, hal.3-31

Dananjaya, Ida B.G. dan Ni Luh Putu Wiagustini. 2015. Studi Komparatif Abnormal Return Sebelum dan Sesudah Merger Pada Perusahaan di BEI. E-Jurnal Manajemen Unud, 4(4), hal.1085-1099.

Darlis, Edfan dan Zirman. 2011. Dampak Publikasi Akuisisi Pada Perusahaan Pengakuisisi. Jurnal Akutansi Fakultas Ekonomi Universitas Riau, 19, hal.22-36

Dewi, Luh Putu Kartika. 2014. Pengujian Pasar Setengah Kuat di Bursa Efek Indonesia. E-Jurnal Manajemen Unud, 3(12), hal.3540-3557.

Edward, M. Yunies. 2012. Analisis Reaksi Pasar Atas Pengumuman Merger dan Akuisisi. Jurnal Dinamika Ekonomi \& Bisnis STIE Nahdlatul Ulama Jepara, 9(1), hal.1-16.

Elad, Fotoh Lazarus. Event Study on the Reaction of Stock Return to Acquisition News. 2017. International Financial and Banking, 4(1). hal 33-43.

Firmansyah, Erdian. 2013. Analisa Pengaruh Pengumuman Akuisisi Terhadap Abnormal return Perusahaan Akuisitor Dan Non Akuisitor Yang Terdaftar Di Bursa Efek Indonesia. Skripsi Sarjana Jurusan AkuntansiUniversitas Pembangunan Nasional.

Gitman, L. J., and Zutter, C. J. 2012. Principles of Managerial Finance. Boston: Prentice Hall.

Hanafi. 2004. Manajemen Keuangan. Yogyakarta: BPFE UGM.

Hartono, Maria Angeline dan L. Jade Faliani. 2012. Pengaruh Merger Atau Akuisisi Terhadap Kinerja Perusahaan dan Harga Saham Perusahaan Publik. Jurnal Telaah Manajemen,7(1), hal. 43-45.

Heykal, M. dan Hennisia, M. 2015. Analisis Hubungan Antara Merger dan AkuisisiTerhadap Kinerja Keuangan dan Return Saham Pada Perbankan yang Terdaftar di BEI. Jurnal Politeknik Negeri Jakarta, 1(3), hal.178186.

Ikatan Akuntan Indonesia (IAI). 2016. Standar Akuntansi Keuangan Efektif Per 1 Januari 2017. http://iaiglobal.or.id/v03/standar-akuntansi-keuangan/sakefektif-3-sak-efektif-per-1-januari-2017. Diakses 12 Oktober 2017.

Imaa. 2017. Acquisition Statistic By Countries. https://imaa-institute.org/m-anda-statistics-countries/. Diakses 9 Desember 2017.

Isa, M., and S. P. Lee. 2011. Method of Payment and Target Status: Announcement Returns to Acquiring Firms in the Malaysian Market. International Journal of Economics and Finance, 3(3), hal.177-189. 
Putu Putri Larasati dan Dewa Gede Wirama. Respon ...

Joash dan Njangiru. 2015. The Effect of Mergers and Acquisitions on Financial Performance of Bank (A Survey of Commercial Bank in Kenya). International Journal of Innovate Research and Development, 4(8), hal. 101-113.

Jogiyanto, H.M. 2015. Teori Portofolio dan Analisis Investasi, Edisi Kesembilan. Yogyakarta: BPFE.

KPPU. 2013. Daftar Perusahaan Yang Melakukan MergerAkuisisi Tahun 2013. http://www.kppu.go.id/id/merger-dan-akuisisi/publikasipemberitahuan/pemberitahuan-merger-2013/. Diakses 12 Oktober 2017.

KPPU. 2014. Daftar Perusahaan Yang Melakukan MergerAkuisisi Tahun 2014. http://www.kppu.go.id/id/merger-dan-akuisisi/publikasipemberitahuan/pemberitahuan-merger-2014/. Diakses 12 Oktober 2017.

KPPU. 2015. Daftar Perusahaan Yang Melakukan MergerAkuisisi Tahun 2015. http://www.kppu.go.id/id/merger-dan-akuisisi/publikasipemberitahuan/pemberitahuan-merger-2015/. Diakses 12 Oktober 2017.

KPPU. 2016. Daftar Perusahaan Yang Melakukan MergerAkuisisi Tahun 2016. http://www.kppu.go.id/id/merger-dan-akuisisi/publikasipemberitahuan/pemberitahuan-merger-2016/. Diakses 12 Oktober 2017

KPPU. 2017. Daftar Perusahaan Yang Melakukan MergerAkuisisi Tahun 2017. http://www.kppu.go.id/id/merger-dan-akuisisi/publikasipemberitahuan/pemberitahuan-merger-2017/. Diakses 12 Oktober 2017.

Khanal, Mishra, dan Mottaleb. 2014. Impact of Merger and Acquisition on Stock Price: The U.S. Ethanol-Based Biofuel Industry. Journal of Biomass and Bioenergy, 61, hal. 138-145.

Kriekhof, Shella. 2001. Pengaruh Metode Pembayaran Dalam Akuisisi Terhadap Abnormal Return Saham Yang Listed Di BEI. Jurnal Sarjana Jurusan Akuntansi Politeknik Negeri Ambon,hal. 419-433.

Liliana, Suhadak, dan Hidayat. 2016. Analisis Dampak Akuisisi Terhadao Return Saham dan Volume Perdagangan (Studi pada Multinational Company yang Terdaftar di BEI Periode 2010-2015). Jurnal Administrasi Bisnisn Universitas Brawijaya, 38(1), hal.60-67.

Mackinlay, A. Craig. 1997. Event Studis in Economics and Finance. Journal of Economic Literature, 34, hal.13-39.

Malau, Wiagustini, dan Artini. 2017. Pengujian Reaksi Pasar Terhadap Peristiwa Merger dan Akuisisi di Bursa Efek Indonesia (BEI). E-Jurnal Ekonomi dan Bisnis Universitas Udayana. 6(9). hal 3325-3352 
Moffett, Clay dan Naserbakht, Mohammad. 2013. Stock Price Behavior of Acquirers and Target Due to M\&A Announcement in USA Banking, Iranian Economic Review, 17(1), hal. 105-114.

Marketeers. 2015. Ini Peyebab Merger dan Akuisisi di Indonesia Lesu. http://marketeers.com/ini-penyebab-merger-dan-akuisisi-di-indonesialesul. Diakses 10 Desember 2017.

Mirna, Didi, dan Niki. 2013. Analysis of Announcement Merger and Acquisition and Payment Method to Stock Return: Study of Listed Companies at BEI During 2005-2011. International Business Research Conference. 36(8), hal 1-13.

Peraturan Pemerintah Republik Indonesia Nomor 57 Tahun 2010 tentang Penggabungan Atau Peleburan Badan Usaha Dan Pengambilalihan Saham Perusahaan Yang Dapat Mengakibatkan Terjadinya Praktik Monopoli Dan Persaingan Usaha Tidak Sehat. 20 Juli 2010. Lembaran Negara Republik Indonesia Nomor 89 Tahun 2010 dan Tambahan Lembaran Negara Nomor 5144. Jakarta.

Rahman, Ali dan Jebran. 2018. The Effect of Merger and Acquisition on Stocl Price Behavior in Banking Sector of Pakistan. The Journal of Finance and Data Science, 4(1), hal. 44-54.

Rani, N., Yadav, S.S., \& Jain, P.K. 2013. Market Response to the Announcement of Merger and Acquisitions: An Empirical Study from India. Journal, 17(1), hal.1-16.

Rowland and Linda. 1994. Trading Volume Reactions To Annual Accounting Earrnings Announcement. Journal of Accounting and Economics, 17, hal.309-329.

Rumondang, Astri. 2010. Analisis Dampak Pengumuman Merger dan AkuisisiTerhadap Abnormal return Saham Perusahaan (Studi Pada Bursa Efek Indonesia Peiode Tahun 2000-2006). SkripsiSarjana Jurusan Akuntansi Universitas Sebelas Maret Surakarta.

Rusnanda, Wahyu Eliya dan Pardi. 2013. Analisa Pengaruh Pengumuman Akuisisi Terhadap Abnormal return Saham Bank Umum Di Bursa Efek Indonesia. Jurnal Graduasi, 29, hal.89-101.

Samsul, Mohamad. 2006. Pasar Modal \& Manajemen Portofolio. Jakarta: Erlangga.

Sanjiwani, Putu Diah Aryastuti dan Jati, I Ketut. 2017. Reaksi Pasar Modal Terhadap Kebijakan Tax Amnesty Pada Saat Pengumuman dan Akhir Periode I. E-Jurnal Akuntansi Universitas Udayana, 19(1), hal.799-826. 
Sartono, R. Agus. 2001. Manajemen Keuangan Teori dan Aplikasi, Edisi 4. Yogyakarta: BPFE.

Suwanna, Thanwarat. 2012. Impact of Devidend Announcement on Stock Return. Journal Faculty of Business Administration, 40, hal.721-725.

Uygur, Meric, dan Meric. 2014. Market Reaction to Acquisition Announcements After The 2008 Stock Market Cash. The International Journal of Business and Finance Research, 8(4), hal.75-82

Wolk, H.I., Dodd, J.L., Rozycki, J.J. 2013. Accounting Theory: ConceptualIssues in a Political and Economic Environment, ${ }^{\text {thEd}} \mathrm{E}$. California: SAGE Publication.

Wong, Anson dan Cheung, Kui Yin. 2009. The Effect of Merger and Acquisition Announcements on the Security Prices of Bidding Firm and Target Firm in Asia. International Journal of Economics and Finance, 1(2), hal. 274-283. 